\title{
FLUCTUATIONS OF SEDIMENTARY ENVIRONMENTS OF THE GYAJO GLACIER, KHUMBU REGION, EAST NEPAL
}

by

HIROJI FUSHIMI

Lake Biwa Research Institute, 1-10, Uchidehama, Ohotsu 520, Japan

Koukichi Kamiyama, Kouichi Kitaoka

Geophysical Research Station, Faculty of Science, Kyoto University, Noguchibaru, Beppu 874, Japan

\section{KOUICHI IKEGAMI}

Water Research Institute, Nagoya University, Chikusa-ku, Nagoya 464, Japan

\section{ABSTRACT}

Studies on the snow-layer stratigraphy were carried out at the Gyajo glacier, Khumbu region, East Nepal from 1973 to 1978. The ages of the snow layers were determined by stratigraphy and tritium analyses, and the fluctuations of sedimentary environments of the Gyajo Glacier, the lower type of a glacier located below $6,000 \mathrm{~m}$ in the Nepal Himalayas, were clarified from 1940 s to 1975 in relation to the climatic changes. The results are: (1) It is likely that one snow layer per year is preserved divided by dirt bands: there are depositional periods ranging for 4-9 years, interrupted by depositional gaps (lacuna) lasting several years. Such stratifications contrast with such higher glaciers as the Khumbu Glacier, where two snow layers per year are formed with continuous deposition. (2) The ages of snow layers were determined by variation of tritium concentrations due to the thermonuclear tests series of 1950s-1970s. From 1940s to 1960 s, the net annual balances have a decreasing trend from 450 to $45 \mathrm{~mm}$, while annual balances are relatively large at the start of the 1970s, ranging from 540 to $270 \mathrm{~mm}$, due to the increased precipitation.

\section{INTRODUCTION}

Studies on the snow stratigraphy were carried out at the Gyajo Glacier, Khumbu region, East Nepal from 1973 to 1978 (Figure 1).

Miller and others (1965) reported that tritium content of the Khumbu glacier shows net annual balance to average 1.7 meters of water equivalent, and there are usually two (summer and winter) layers per year. The accumulation area of the Gyajo Glacier (Figure 2), typical of lower glaciers with accumulation area below $6,000 \mathrm{~m}$, is located nearly at the snow-rain boundary in the summer monsoon, the main accumulation season, and then the sedimentary environments must be unstable in contrast to higher glaciers such as the Khumbu Glacier, originating from $8,000 \mathrm{~m}$. Fushimi (1977) reported firn stratigraphy on the Gyajo Glacier to show alternations of depositional and erosional (hiatus) years. Since the ages of the snow layers were determined by stratigraphic studies and tritium analyses, the fluctuations of sedimentary environments of the Gyajo Glacier are discussed in relation to climatic changes.

\section{STRATIGRAPHIC STUDIES}

In the summer monsoon season, firn snow becomes a homgeneous granular snow with grain size 1-4 mm and mean density $0.45 \mathrm{~g} / \mathrm{cm}^{3}$. Dirt bands composed of clays, sands and organic materials were observed in the firn snow as well as in the glacier ice, and can be used as the key bed for dividing snow layers of the firn.

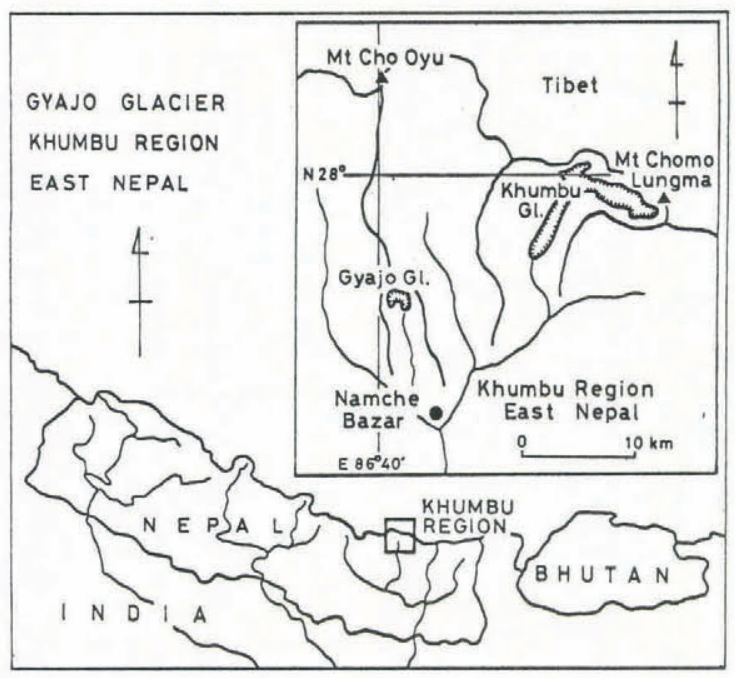

Fig.1. Gyajo and Khumbu Glaciers, Khumbu region, East Nepal.

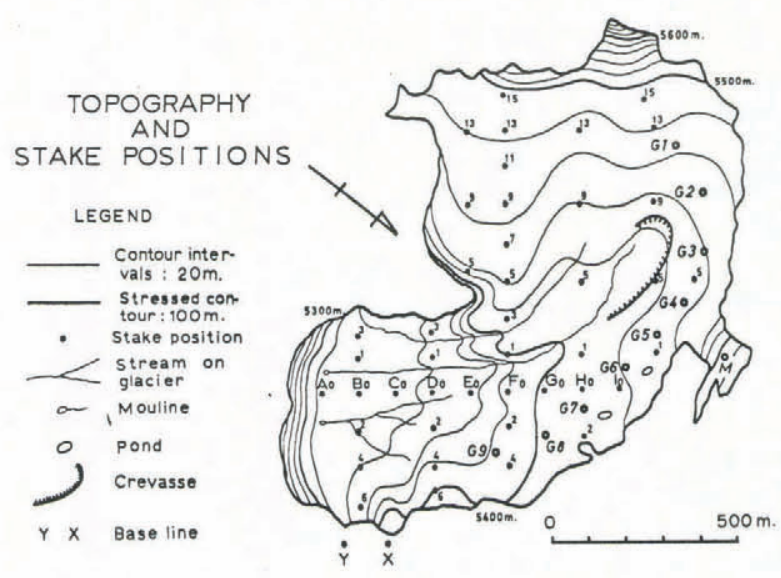

Fig.2. Topography of the Gyajo Glacier and stake positions. stratigraphic studies were made at Gl-G9, shown by thick circles. Members of snow layers were studied and sampled at $\mathrm{M}$ in the upper accumulation area. 


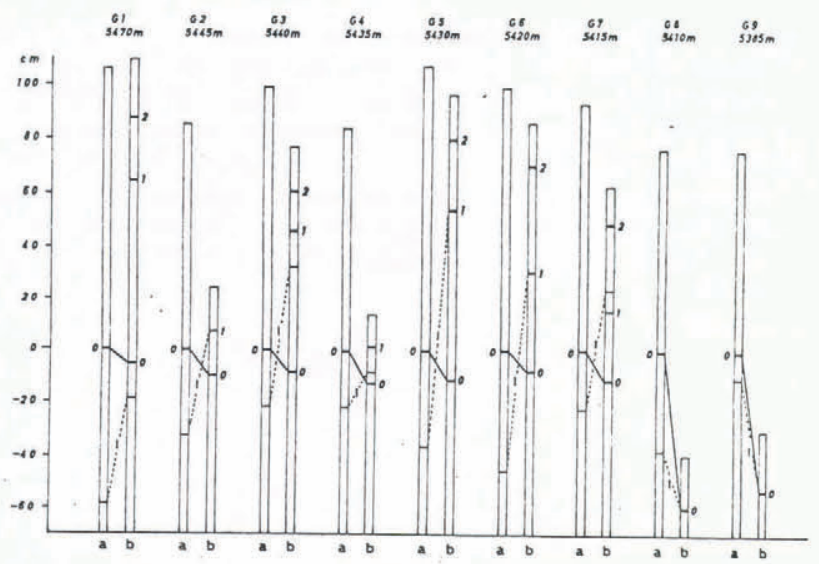

Fig.3. 1976(a)-1978(b) stratigraphic changes of firn snow at the Gyajo Glacier. The depth $(0 \mathrm{~m})$ is based on the position of the 1976 dirt band. Numbers 1 and 2 indicate new dirt bands, and (I) shows the surface of the super-imposed ice.

Figure 3 shows stratigraphic changes during 1976-1978 at 9 points (G1-G9 in Figure 2) in the Gyajo Glacier. The formations of the superimposed ice and snow layers with new dirt bands indicate that the accumulation area is located above $5,415 \mathrm{~m}$ (G7), because two snow layers at 5 points (G1, G3, G5-7) and one snow layer at 2 points (G2, G4) were observed with the superimposed ice during these two years, and no snow layers and superimposed ice occurred below $5,410 \mathrm{~m}$ (G8) where the ablation area is thought to be.

The dirt band may be formed in the dry (winter) season when the wind is strong. Its formation is interrupted by snowfalls in winter, and this causes multiple dirt bands to be formed in year of balance: but there is also a process which acts to change the snow layers and dirt bands. When the temperature of the firn snow reaches melting point during the early part of the summer monsoon season, the surface melts, the snow layer is reduced to zero, and two layers of dirt bands amalgamate (Fushimi 1978). So it seems likely that several dirt bands combine to form one layer unless the winter accumulation is large enough to preserve them during the melt season.

Ageta and Satow (1978) reported that glacier mass balance of the Nepal Himalayas is characterized by the simultaneous occurrence of considerable accumulation and ablation during the summer monsoon season, and that balance is attributed mainly to accumulation in late summer. So it is likely that only one (summer) snow layer is preserved during balance years in the lower glaciers of the Nepal Himalayas, in contrast to the higher glaciers where two snow layers form per year and depositional periods are continuous.

The snow layers at $\mathrm{M}(5,500 \mathrm{~m})$ in the firn area of the Gyajo Glacier (Figure 2) are divided into 7 members (A-G) by unconformities (a-g), showing the possibility of a depositional gap (lacuna) of snow layers (Figure 4). Each member is composed of 4 to 9 snow layers as follows: A1-A5, B1-B5, C1-C5, D1-D4, E1-E9, F1-F8 and G1-G4.

Since G4 is the snow layer of the year 1975 and is thought to be the continuous deposition with one snow layer per year during the formation of the $G$ member, the date of snow layer G3 is 1974, G2 1973 and G1 1972. Changes of thickness of the snow layer indicate the variation of the sedimentary environments. There are large fluctuations of thickness from 10 to $120 \mathrm{~cm}$ found in snow layers from members $A$ to $F$, and the snow layer becomes thinner in members $E$ and $F$. It is remarkable that the thickness of snow layers again increses from the start of the G depositional years in the early 1970s.

The net annual deposition of snow, especially in the lower glaciers, is not always continuous through many years: interruption in erosional years shows as an unconformity, but depositional periods may last from 4 to 9 years.
THICKNESS OF SNOW LAYERS

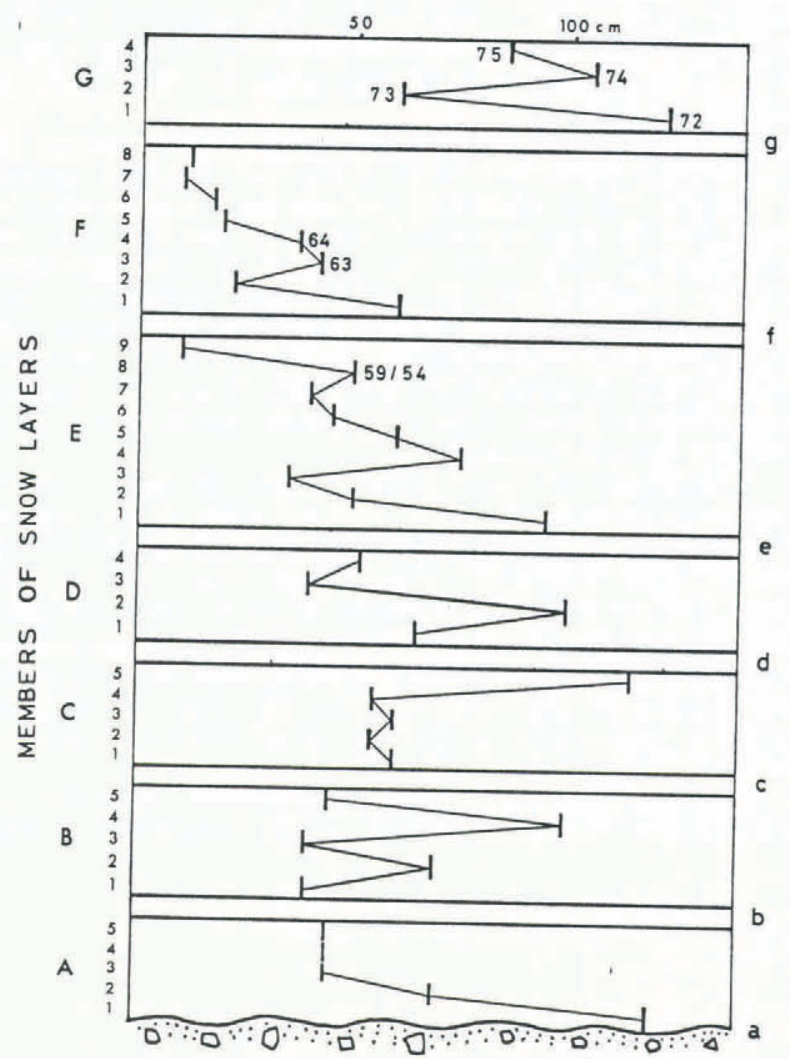

Fig.4. Changes of thickness of snow layers A1-G4. (a)-(g) indicate unconformities.

\section{DATING BY TRITIUM ANALYSES AND FLUCTUATION OF SEDIMENTARY ENVIRONMENTS}

The exact durations of the depositional gaps indicated by unconformities (lacuna) were not apparent from stratigraphic studies, so the ages of the snow layers were identified by correlation with variations of tritium concentrations. Miller and others (1965) and Kamiyama and Kitaoka (1984) provided a vertical profile of tritium content in the glaciers of the Nepal Himalayas, and reported that peaks exist due to the thermonuclear test series.

Figure 5 shows the profile of concentrations in

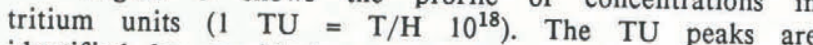
identified by considering measurements made according to

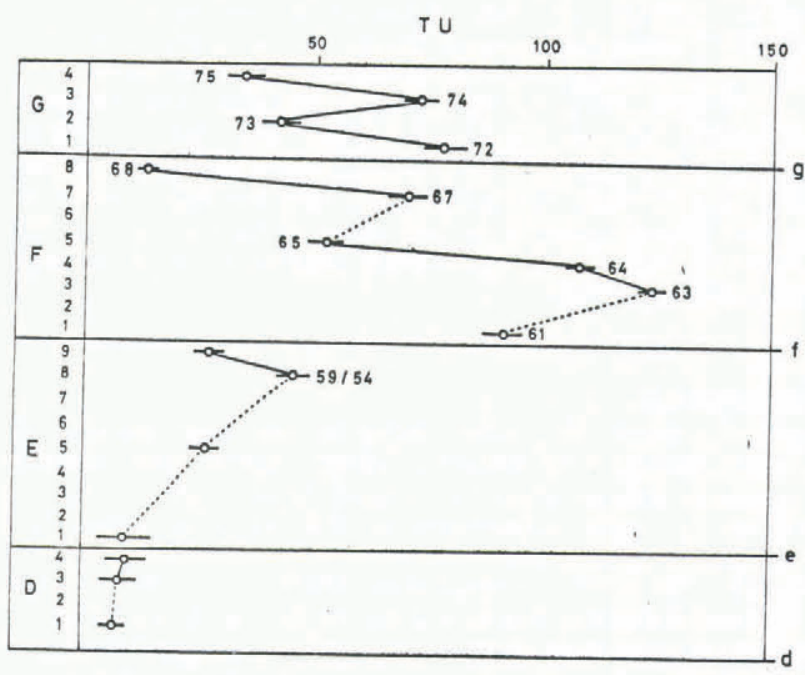

Fig.5. Changes of tritium concentration (TU) in D-G members of snow layers. The TU values are represented as those in October 1983. 
tritium data in precipitation at New Delhi, India and Tokyo, Japan (IAEA 1969-1979). The maximum tritium peak occurs in 1963-64 with 500-600 TU in New Delhi; other peaks of less than $200 \mathrm{TU}$ occur in 1974, 1970-71, 1958-59 and 1954.

Since the maximum tritium concentration appears in the F4 snow layer, the F3-F4 layers were probably formed in 1963-64. It is interesting that the peak concentration is about $400 \mathrm{TU}$ (age corrected), similar to the TU value of New Delhi in 1964. The small peak in the G3 snow layer can be correlated to the 1974 peak, coinciding with stratigraphic results, and the date of the E8 snow layer will be 1959 or 1954. Consequently, the ages of the G members are 1972-75, F members (F1-F8) 1961-68 and E members from 1940s to 1950s. Ages of the snow layers in the D-A members are still unknown.

Thickness of snow layers (Figure 4) in $\mathrm{E}$ and $\mathrm{F}$ members decreases from $100 \mathrm{~cm}$ in $1940 \mathrm{~s}$ to $10 \mathrm{~cm}$ in 1968 , and the net annual balances range from 450 to 45 $\mathrm{mm}$ of water equivalent, with average density $0.45 \mathrm{~g} / \mathrm{cm}^{3}$. From 1972 to 1975, the thickness of snow layers increased to range 120 to $60 \mathrm{~cm}(540-270 \mathrm{~mm}$ of water equivalent) during the formation of the $G$ member, after three years of the depositional gap 1969-71. The TU peaks (Figure 5) coincided with peaks of the net annual balance (Figure 4) of 1974, 1963-64, and 1959/1954.

Figure 6 shows the characteristic increase in precipitation and slight increase in air temperature during

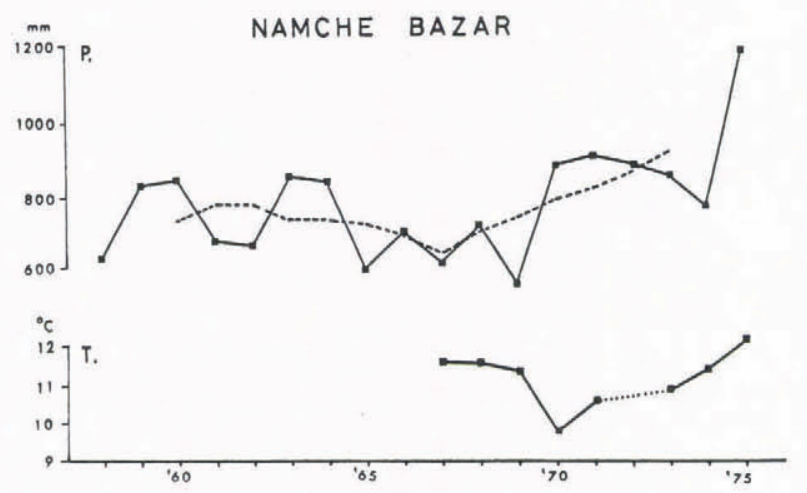

Fig.6. Changes of precipitation (upper) and air temperature (lower) during the monsoon season (June-September) at Namche Bazar, Khumbu region. The dotted line shows the three years running mean of the precipitation.

the early 1970s at Namche Bazar about $10 \mathrm{~km}$ south of the Gyajo Glacier. Since the rising air temperature has a negative effect in the sedimentary environment, the preferable sedimentary environments in the early 1970s are thought to be mainly caused by increasing precipitation.

Fushimi and others (1981), studying the terminal fluctuations of 14 glaciers including the Gyajo Glacier, reported that most of the termini were receding in the 1970 s due to rising air temperature. The increasing trend of the net annual balances in the early 1970 s has not so far caused the advance of the Gyajo Glacier terminal through increased glacier flow.

\section{REFERENCES}

Ageta Y, Satow K 1978 Study of the mass balance of small glaciers in Khumbu Himal during the summer monsoon season. Seppyo 40 Special Issue: 4-11

Fushimi H 1977 Glaciations in the Khumbu Himal (1). Seppyo 39 Special Issue: 60-67

Fushimi H 1978 Stratigraphic studies of the Gyajo Glacier, Khumbu Himal. Seppyo 40 Special Issue: 17-20

Fushimi H, Ohata T, Higuchi K 1981 Recent fluctuations of glaciers in the eastern part of Nepal Himalayas. Proceedings of the Symposium "Sea level, ice sheet and climatic change", International Association of Hydrological Sciences, publ. no 131: 21-29
IAEA (1969-1979) Environmental isotope data no 1-6. World survey of isotope concentration in precipitation (1953-1975). Technical Report Series 96/117/129/147 $/ 165 / 192$, Vienna, International Atomic Energy Agency,

Kamiyama K, Kitaoka K 1984 Characteristics of Yala Glacier from the viewpoint of tritium content. In Higuchi $\mathrm{K}$ (ed) Report of the Glacier Boring Project 1981-82 in the Nepal Himalaya. Japanese Society of Snow and Ice: $35-40$ 